\title{
The >494 Ma Lillevik ophiolite fragment (Gratangseidet Igneous Complex) near Narvik, Scandinavian Caledonides
}

\author{
Trond Slagstad ${ }^{1}$, Mark Anderson ${ }^{2}$, Kerstin Saalmann ${ }^{1} \&$ Graham Hagen-Peter ${ }^{1}$ \\ ${ }^{1}$ Geological Survey of Norway, 7491 Trondheim, Norway. \\ ${ }^{2}$ School of Geography, Earth and Environmental Sciences, Plymouth University, Plymouth, UK. \\ E-mail corresponding author (Trond Slagstad): trond.slagstad@ngu.no
}

Keywords:

- Lillevik ophiolite fragment

- Caledonides

- Ophiolite

- Cambrian

- Electronic Supplement 1. $\mathrm{U}$-Pb zircon geo-

chronological data

- Electronic Supplement 2. Lu-Hf zircon isotopic data

- Electronic Supplement 3. Whole-rock geochemical data

Received:

1. September 2020

Accepted:

22. December 2020

Published online:

5. January 2021
One of several irregular, plagioclase-phyric felsic veins in the Lillevik ophiolite fragment (Gratangseidet Igneous Complex) in Narvik, northern Norway, yielded a U-Pb zircon age of $494 \pm 5 \mathrm{Ma}$. The veins cut deformed, compositionally layered, light REE-depleted gabbros that arguably constituted part of the now-dismembered ophiolite stratigraphy. The felsic veins were themselves deformed, probably during Silurian Scandian deformation, but the cross-cutting relationships suggest that they post-date initial deformation of the ophiolitic rocks. The felsic veins are strongly depleted in heavy REE and have moderately juvenile Lu-Hf zircon compositions, with $\varepsilon \mathrm{Hf} 494$ between 6.2 and 9.9. By analogy with felsic rocks in other Caledonian ophiolites and supported by cross-cutting relationships, the chemical and isotopic data can be interpreted to reflect formation by partial melting of basaltic rocks in the presence of residual garnet. In this case, the felsic veins probably post-date ophiolite formation and obduction onto a continental margin. We therefore interpret the age of $494 \mathrm{Ma}$ to represent the minimum age of formation of the Lillevik ophiolite fragment. Previously published age, isotopic and chemical data from the region document an at least 20 Myr-long complex magmatic evolution following ophiolite obduction. The new data show that Late Cambrian to Early Ordovician ophiolite fragments extend along most of the length of the Scandinavian Caledonides. The tectonic significance of a previously published age of $474 \mathrm{Ma}$ from the Gratangseidet Igneous Complex and 481 to 469 Ma ages from a tonalite sheet in the nearby Lyngen ophiolite, both interpreted to reflect ophiolite formation, needs to be tested by obtaining whole-rock geochemical data from these units.

\section{Introduction}

The Scandinavian Caledonides formed during Late Cambrian through Ordovician convergence and closure of the lapetus Ocean, followed by Early Silurian (c. 440-430 Ma) continent-continent collision between Baltica and Laurentia. This long-lived convergence resulted in complex nappe stacks that were assembled partly prior to collision and partly during southeastward thrusting onto Baltica during collision. An important tenet in studies of Caledonian geology is that seemingly correlative units can be traced for hundreds of kilometres along the length of orogen (Gee et al., 1985; Roberts \& Gee, 1985). Although recent studies have found that certain components of Caledonian geology can indeed be correlated for hundreds

Slagstad, T., Anderson, M., Saalmann, K. \& Hagen-Peter, G. 2020: The >494 Ma Lillevik ophiolite fragment (Gratangseidet Igneous Complex) near Narvik, Scandinavian Caledonides. Norwegian Journal of Geology 100, 202022. https://dx.doi.org/10.17850/njg100-4-5.

This work is licensed under a Creative Commons Attribution 4.0 International License. 
of kilometres (Slagstad \& Kirkland, 2018), it has been argued that such a general scheme is likely to be too rigid and simplistic (Corfu et al., 2014) or difficult to test (Slagstad \& Kirkland, 2017).

Late Cambrian to Early Ordovician ophiolite complexes are common from the southwestern Scandinavian Caledonides up through the Trondheim Region (Fig. 1). These complexes variably preserve evidence of changing tectonic environments, e.g., from subduction-influenced, oceanic back-arc basin to mid-ocean spreading ridge (497 Ma Leka ophiolite; Furnes et al., 1988), or from ocean-floor formation followed by establishment of an island arc (487-482 Ma Løkken ophiolite; Grenne, 1989). Other ophiolites, such as the 486 Ma Bymarka ophiolite (Slagstad, 2003; Slagstad et al., 2013), preserve a complete record from ocean-floor spreading (486 Ma) through convergence (481 $\mathrm{Ma}$ ) and post-obduction magmatism (468 Ma). The results from the Bymarka ophiolite show that dating felsic rocks in ophiolites can lead to a range of ages, and that some consideration of petrogenesis is needed in order to interpret the tectonic significance of those ages.

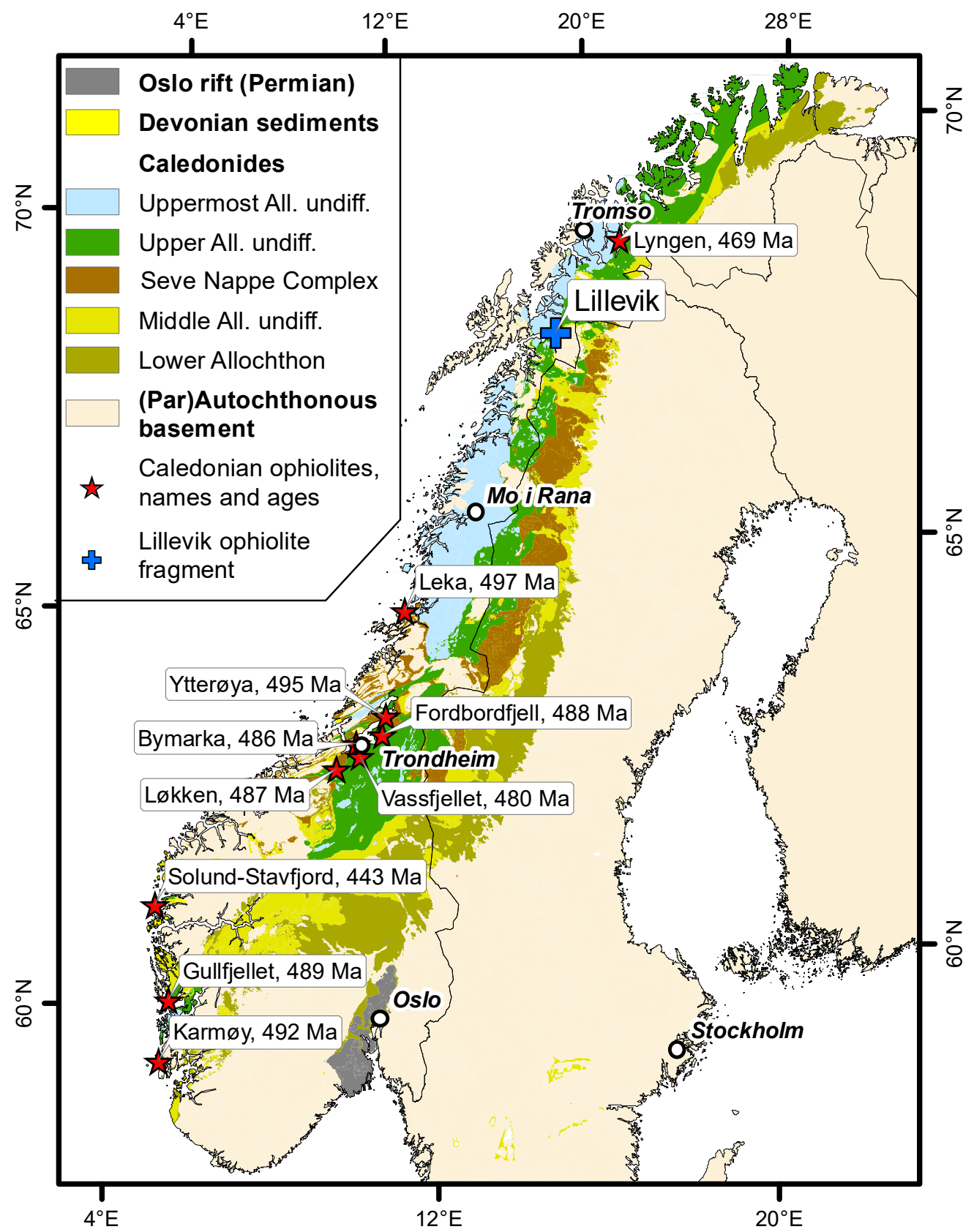

Figure 1. (A) Simplified map of the Scandinavian Caledonides, modified from Roberts \& Gee (1985), with locations and formation ages of ophiolites and ophiolite fragments. 
In the northern Scandinavian Caledonides, ages derived from ophiolitic rocks include deformed tonalites from the Lyngen ophiolite yielding ages of $481 \pm 6$ and $469 \pm 5$ Ma (Oliver \& Krogh, 1995; Augland et al., 2014), a tonalite from the Gratangseidet Igneous Complex, about a kilometre from the Lillevik ophiolite fragment, yielding an age of $474 \pm 0.7 \mathrm{Ma}$ (Augland et al., 2014), and the Ruggevik tonalite yielding an age of $479 \pm 1 \mathrm{Ma}$ (Northrup, 1997). These ages were interpreted to reflect the ages of ophiolite formation but are younger than plagiogranites in other Caledonian ophiolites that typically yield ages between c. 497 and $480 \mathrm{Ma}$ and are shown to be comagmatic with the mafic rocks making up the ophiolites based on geochemical and isotopic data (Dunning \& Pedersen, 1988; Slagstad et al., 2013).

Here, we present new $\mathrm{U}-\mathrm{Pb}$ zircon age and Lu-Hf isotopic data and whole-rock geochemistry from a felsic vein in the c. 50 m-wide Lillevik ophiolite fragment in the town of Narvik (Fig. 1), northern Scandinavian Caledonides, and briefly discuss its significance for the pre-Scandian magmatic evolution of the Gratangseidet Igneous Complex and correlation with ophiolites elsewhere in the Scandinavian Caledonides.

\section{Regional geology}

Since the seminal works of Gee et al. (1985), Roberts \& Gee (1985) and Stephens et al. (1985), the Scandinavian Caledonides have typically been described in terms of four allochthons, each comprising a series of nappe complexes (Fig. 1). The Upper and Uppermost allochthons are generally inferred to be exotic to Baltica, probably of lapetan and Laurentian heritage, respectively, whereas the Lower and Middle allochthons are assumed to represent the outer continental margin of Baltica, telescoped during the Silurian Scandian orogenic event. There is, however, ample evidence for a long, complex and as yet poorly constrained, Neoproterozoic through Ordovician, tectonometamorphic and magmatic history in all allochthons but the Lower (e.g., Kirkland et al., 2007; Gasser et al., 2015; Jakob et al., 2017; Slagstad et al., 2020). The evidence, however, is generally overprinted by c. 440-430 Ma highgrade metamorphism related to initial nappe assembly (e.g., Kirkland et al., 2018; Bender et al., 2019; Faber et al., 2019), and further structural reorganisation associated with final thrusting over Baltica at c. 420-400 Ma (e.g., Hacker \& Gans, 2005; Froitzheim et al., 2016).

The Caledonian geology of the Ofoten area is dominated by a major Scandian structure, the Ofoten synform, located between the Rombak tectonic basement window to the east and the VesterålenLofoten basement complex to the west (Figs. 1 \& 2A). The dominant unit in the study area, which lies along the southeastern limb of the Ofoten synform, is the Narvik Nappe Complex, in turn structurally overlain by the Ofoten Nappe Complex (Steltenpohl et al., 1990). The Narvik Nappe Complex constitutes the Upper Allochthon in this area, whilst the Ofoten Nappe Complex constitutes the lower part of the Uppermost Allochthon (Gee et al., 1985). Both consist of several thrust sheets although the precise internal tectonostratigraphy is debated (Augland et al., 2014). The Narvik Nappe Complex comprises amphibolite-facies garnet-mica schists, calcareous mica schists, biotite schists with minor amphibolite and other metamfic rocks (e.g., Hodges, 1985). The overlying Ofoten Nappe Complexconsists of at least three lithotectonic units: from bottom to top, the Gratangseidet Igneous Complex, the Evenes Group and the Bogen Group (Augland et al., 2014) The Gratangseidet Igneous Complex consists of variably deformed metaign us rocks several of which are interpreted as being ophiolitic in character, including the Lillevik ophiolite fragment, which is the focus of this study. U-Pb zircon dating of an isotopically primitive $\left(\varepsilon \mathrm{Hf}_{474}=9.57\right)$ tonalite from the Gratangseidet Igneous Complex yielded an age of $474 \mathrm{Ma}$ (Fig. 2A), interpreted by Augland et al. (2014) to represent the age of ophiolite formation. The contact to the overlying Evenes Group is interpreted either as a deformed depositional contact 

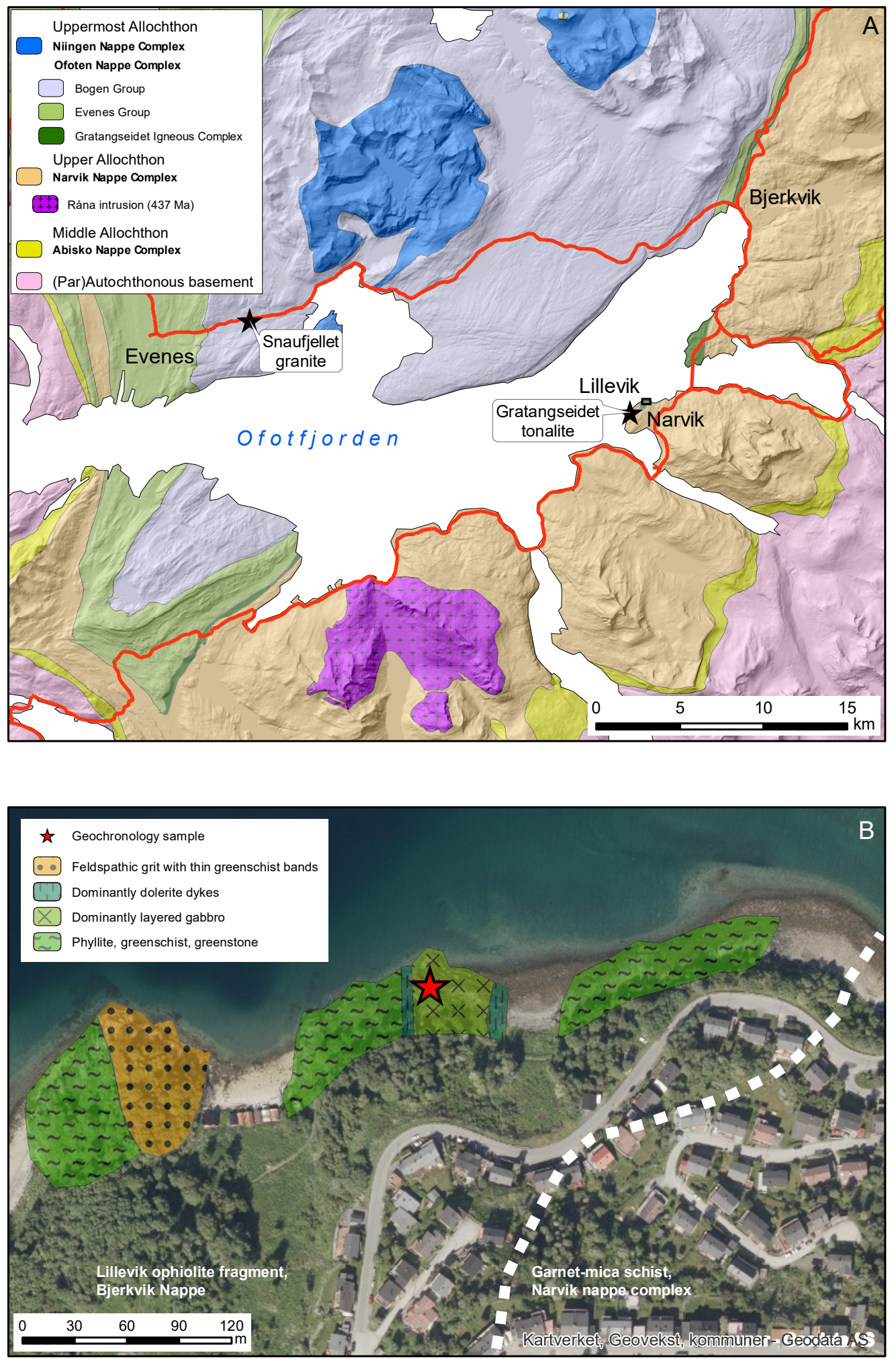

Figure 2. (A) Simplified regional map of the Ofotfjorden area. Modified after Gustavson (1974), Zwaan et al. (1998) and Melezhik et al. (2003). The locations of two previously published ages from the region have been indicated as black stars, both from Augland et al. (2014). The isotopically juvenile Gratangseidet tonalite ( $474 \mathrm{Ma})$ is from the same unit as our sample from the Lillevik ophiolite fragment. The isotopically evolved A-type Snaufjellet granite sill (Augland et al., 2014) is located in the Bogen Group. (B) Geological map of the Lillevik ophiolite fragment, modified after Boyd (Boyd, 1983), with the red star marking the location of sample 133119. 
(Steltenpohl et al., 1990; Andresen \& Steltenpohl, 1994) or a purely tectonic contact (Melezhik et al., 2002a; Melezhik et al., 2002b). The Evenes and structurally overlying Bogen Group consist predominantly of a variety of schists and marbles. Isotope chemostratigraphy $(\mathrm{Sr}, \mathrm{C})$ on the marbles has been interpreted in terms of a complex nappe stack comprising both Neoproterozoic and OrdovicianSilurian marble units (Melezhik et al., 2002a; Melezhik et al., 2002b). The same method has been used to determine similar Neoproterozoic depositional ages for other marble occurrences elsewhere in the Uppermost Allochthon (Slagstad et al., 2006; Melezhik et al., 2015; Melezhik et al., 2018), whereas younger, Cambrian-Ordovician depositional ages have been determined for marbles in the Upper Allochthon, suggesting that the Ofoten Nappe Complex may comprise components of both allochthons. Alternatively, as discussed by several authors, the distinction between the Upper and Uppermost allochthons may be somewhat diffuse (Meyer et al., 2003; Corfu et al., 2014; Slagstad et al., 2020). An age of $474 \mathrm{Ma}$ from an isotopically evolved $\left(\varepsilon \mathrm{Hf}_{474}=-6.22\right)$ A-type granite sill in the Bogen Group has been presented by Augland et al. (2014).

\section{Geology of the Lillevik ophiolite fragment}

The lithologies and field relationships of the Lillevik ophiolite fragment were described in detail by Boyd (1983). The fragment is only about $50 \mathrm{~m}$ wide (Fig. 2B) and appears to form a tectonic lens within a sequence of sulphide- and graphite-bearing phyllites and some mafic rocks that were tight to isoclinally folded followed by more open folding. The dominant rock type is layered hornblende gabbro (Fig. 3D), which consists dominantly of hornblende and saussuritised plagioclase and is characterised by either faint, centimetre- to decimetre-scale, medium-grained modal layering, or decimetre-scale layers of harrisitic hornblende with grains up to $30 \mathrm{~cm}$ long, alternating with plagioclase-dominated layers. The layered gabbros are cut by several generations of fine-grained dolerite dykes, gabbro dykes and plagioclase-phyric felsic veins (Fig. 3). These features were interpreted by Boyd (1983) to reflect the transition zone between the cumulate gabbros and sheeted dyke complex, commonly observed in ophiolite complexes. In dtail, two generations of dolerite dyke cut the layered gabbro, with younger mafic and gabbro dykes cutting all felsic veins in their immediate vicinity. The compositionally layered gabbros are localy deformed, shown by alignment of fine-grained mafic minerals. The tectonic foliation is clearly different from the compositional layering, which is largely made up of variable proportions of mafic and felsic, unoriented minerals. At least two generations of felsic veins and one or more generations of mafic dykes postdate the deformation of the layered gabbros (Fig. 3A-D). We note that due to the nature of the outcrop, we were unable to sample demonstrably cross-cutting felsic veins and had to settle for a vein with indeterminate relationships to its host rock, but with a similar plagioclase-phyric texture and appearance to the oldest generation of cross-cutting veins. In the following discussion we will refer to five lithologies: (1) 'layered gabbros', representing the oldest rocks in the Lillevik ophiolite fragment; (2) 'mafic' dykes, representing mafic magmatism that is either coeval with or younger than that forming the layered gabbros; (3) 'felsic veins', including the sample dated by us, that clearly cut the layered gabbros; (4) 'gabbroic dykes' that post-date the felsic veins; (5) 'cross-cutting dolerite dykes' that post-date deformation of the ophiolite fragment. 

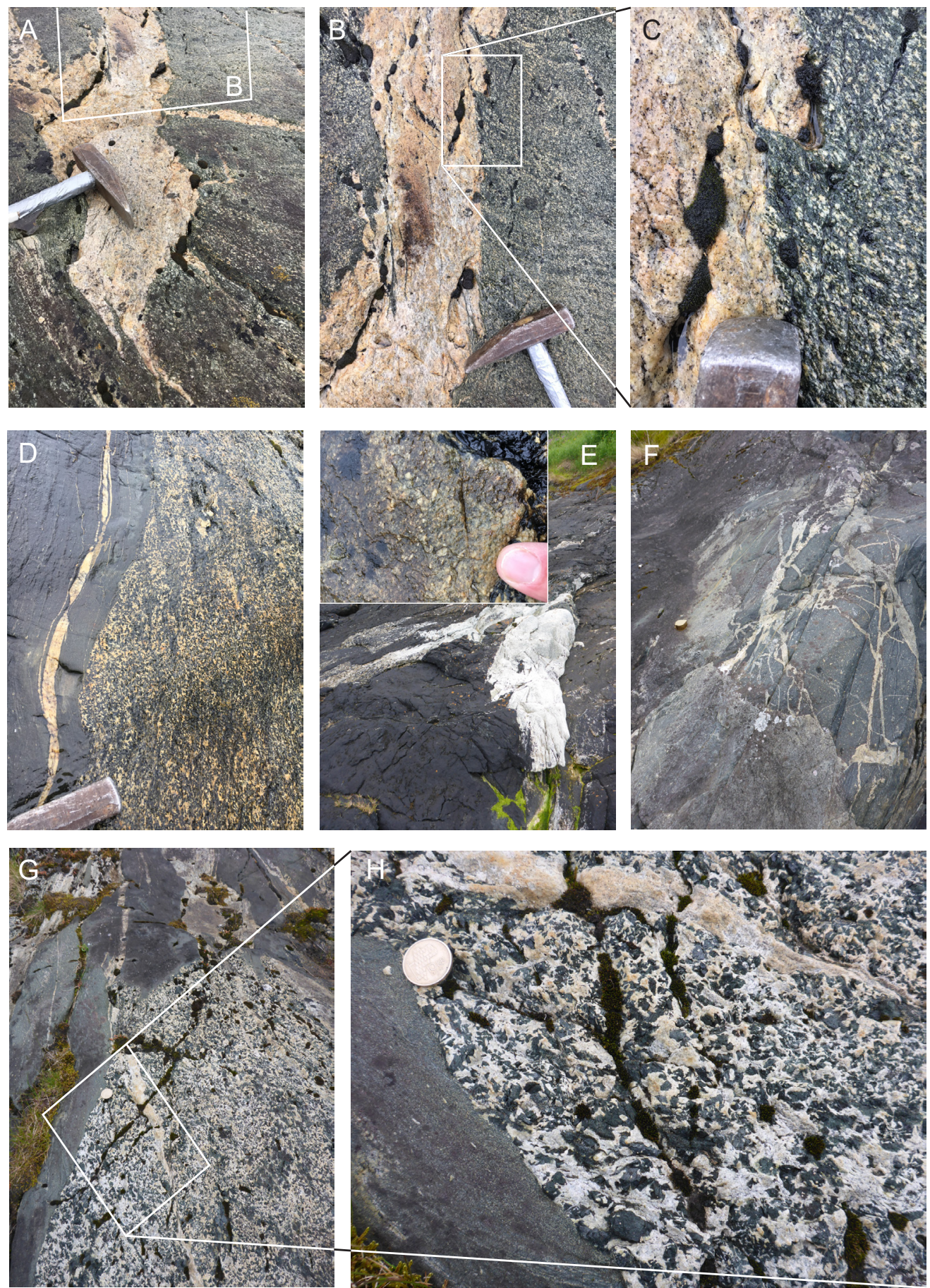

Figure 3. Field photos from the Lillevik ophiolite fragment. (A, B, C) Irregular, deformed felsic vein cutting compositional layering in gabbro and superimposed tectonic foliation. (D) Dolerite dyke cutting compositional layering in gabbro. The dolerite dyke contains an injectedfelsicvein, followed bystrong deformation and boudinage of the vein. (E) Dated felsic vein. Cross-cutting relationships are difficult to identify for this particular vein due to a dense cover of algae. Inset: Close-up of the dated felsic vein showing that it is plagioclase phyric. (F) Two generations of felsic veins in the Lillevik ophiolite fragment; an older generation of light-coloured veins cut by younger, grey veins and dykes. The dated sample represents the older generation of dykes. The younger generation could not be sampled. $(G, H)$ Coarse-grained gabbro dyke cutting tectonic fabric in dolerite. 


\section{Methods}

\section{$\mathrm{U}-\mathrm{Pb}$ zircon geochronology}

Zircon grains were separated from crushed and sieved $(<250 \mu \mathrm{m})$ rock samples using standard water-table, heavy-liquid and magnetic (Frantz) techniques. U-Pb zircon geochronological analyses were carried out at the Geological Survey of Norway (NGU) on an ELEMENT XR single collector, highresolution ICP-MS, coupled to a UP193-FX 193 nm, short-pulse, excimer laser ablation (LA) system from New Wave Research. The analyses were conducted in two rounds. First, the zircon grains were placed on double-sided tape and ablated twice, the first time with a $30 \mu \mathrm{m}$-wide line, at a laser fluence of $1 \mathrm{~J} / \mathrm{cm}^{2}$ and frequency of $10 \mathrm{~Hz}$, to remove the outermost surface of the grain, followed by ablation along the earlier track using a $15 \mu \mathrm{m}$-wide line, laser fluence of $3 \mathrm{~J} / \mathrm{m}^{2}$ and frequency of $10 \mathrm{~Hz}$. The purpose of this procedure was to analyse potential thin rims on the grains that would be difficult to analyse in a sectioned grain. Some grains were also cast in epoxy and polished to reveal internal zoning and imaged by back-scatter electron (BSE) and cathodoluminescence (CL) prior to LA-ICP-MS analysis. The laser was set to ablate single, up to $60 \mu \mathrm{m}$-long lines, using a spot size of $15 \mu \mathrm{m}$, a repetition rate of $10 \mathrm{~Hz}$ and an energy corresponding to a fluence of $3 \mathrm{~J} / \mathrm{cm}^{2}$. In both rounds, each analysis included 30 s of background measurement followed by 30 s of ablation. Masses 202, 204, 206-208, 232 and 238 were measured. The reference material GJ-1 (Jackson et al., 2004) was used for fractionation and drift corrections for isotopic ratios, whereas 91500 (Wiedenbeck et al., 1995), Temora (Black et al., 2003) and an in-house standard (OS-99-14; $1797 \pm 3 \mathrm{Ma}$; Skår, 2002) were used to evaluate accuracy and repeatability. The OS-99-14 reference zircon demonstrates variable degrees of discordance (Skår, 2002) and is thus used here to evaluate the accuracy and repeatability only of ${ }^{207} \mathrm{~Pb} /{ }^{206} \mathrm{~Pb}$ dates. The reproducibility (mean $\pm 2 \mathrm{SD}$ ) of the ${ }^{206} \mathrm{~Pb} /{ }^{238} \mathrm{U}$ ages (excluding the discordant OS-99-14) of quality-control reference zircons is as follows: 91500: $1072 \pm 51 \mathrm{Ma}(\mathrm{n}=28)$; Temora: 417 $\pm 16 \mathrm{Ma}\left(\mathrm{n}=28\right.$ ). The reproducibility (mean $\pm 2 \mathrm{SD}$ ) of the ${ }^{207} \mathrm{~Pb} /{ }^{206} \mathrm{~Pb}$ ages for $\mathrm{OS}-99-14$ is $1799 \pm 30 \mathrm{Ma}$. To account for excess variance in the ${ }^{206} \mathrm{~Pb} /{ }^{238} \mathrm{U}$ dates, an additional $1.5 \%$ was quadratically added to the internal uncertainty of ${ }^{206} \mathrm{~Pb} /{ }^{238} \mathrm{U}$ dates from individual analyses, as this was the magnitude required to yield an MSWD $=1$ for a weighted-mean ${ }^{206} \mathrm{~Pb} / 238 \mathrm{U}$ age for Temora. No additional uncertainty propagation was required for the ${ }^{207} \mathrm{~Pb} /{ }^{206} \mathrm{~Pb}$ dates (i.e., MSWD $=0.57$ for the weighted-mean ${ }^{207} \mathrm{~Pb} /{ }^{206} \mathrm{~Pb}$ age for OS-99-14). The data were not corrected for common lead but monitoring of the signal for 204 allowed exclusion of data deemed to be influenced by common $\mathrm{Pb}$ from further calculations. The data were reduced using GLITTER ${ }^{\circledR}$ (Van Achterbergh et al., 2001). All U-Pb zircon geochronological data were plotted and ages calculated using IsoplotR (Vermeesch, 2018).

\section{Lu-Hf isotopes in zircon}

The $\mathrm{Hf}$ isotope compositions of the dated zircons were determined by LA-MC-ICP-MS at the Geological Survey of Norway (NGU) using a Photon Machines Analyte Excite $193 \mathrm{~nm}$ excimer laser connected to a Nu Plasma 3 MC-ICP-MS. Forty $\mu \mathrm{m}$-diameter spots were placed overlapping the tracks ablated for $\mathrm{U}-\mathrm{Pb}$ dating, or in the same textural domains identified in $\mathrm{CL}$ images. Ablations were carried out in a two-volume laser cell in a He atmosphere using a laser fluence of $4 \mathrm{~J} / \mathrm{cm}^{2}$ and a repetition rate of 8 or $9 \mathrm{~Hz}$. The sample aerosol was transported in $\mathrm{He}$ to the plasma torch, and $\mathrm{Ar}$ was added to the $\mathrm{He}$ carrier gas in a glass mixing bulb 1 $\mathrm{m}$ 'upstream' of the torch. Baseline, ablation, and washout times were 35,45 and $10 \mathrm{~s}$, respectively. The following isotopes were measured on Faraday cups with $10^{11} \Omega$ resistors in static mode: ${ }^{171} \mathrm{Yb},{ }^{172} \mathrm{Yb},{ }^{173} \mathrm{Yb},{ }^{174}(\mathrm{Yb}, \mathrm{Hf}),{ }^{175} \mathrm{Lu},{ }^{176}(\mathrm{Hf}, \mathrm{Yb}, \mathrm{Lu}),{ }^{177} \mathrm{Hf},{ }^{178} \mathrm{Hf},{ }^{179} \mathrm{Hf}$ and ${ }^{180} \mathrm{Hf}$. The following reference zircons were measured throughout the analytical session: Plešovice $(176 \mathrm{Hf} / 177 \mathrm{Hf}$ $=0.282482$, Sláma et al., 2008), MUNZirc 1, 3, and $4(176 \mathrm{Hf} / 177 \mathrm{Hf}=0.282140$, Fisher et al., 2011), 
Mud Tank $(176 \mathrm{Hf} / 177 \mathrm{Hf}=0.282140$, Woodhead \& Hergt, 2005) and $91500(176 \mathrm{Hf} / 177 \mathrm{Hf}=0.282308$, Blichert-Toft, 2008). Plešovice and MUNZirc 4 were analysed at the beginning and end of each sequence, as well as between every 8-10 measurements of samples and other reference zircons.

Data reduction was done using a custom data reduction scheme in lolite v. 3.71. Hafnium mass bias ( $\beta \mathrm{Hf}$ ) was calculated relative to ${ }^{179} \mathrm{Hf} /{ }^{177} \mathrm{Hf}=0.7325$ (Patchett \& Tatsumoto, 1980, 1981). Ytterbium mass bias $\left(\beta \mathrm{Yb}\right.$ ) was calculated relative to ${ }^{173} \mathrm{Yb} /{ }^{171} \mathrm{Yb}=1.130172$ (Segal et al., 2003). The exponential mass-bias law was used throughout. Interferences from ${ }^{176} \mathrm{Yb}$ and ${ }^{176} \mathrm{Lu}$ on ${ }^{176} \mathrm{Hf}$ were subtracted from the total ${ }^{176}(\mathrm{Hf}$, $\mathrm{Yb}, \mathrm{Lu}$ ) signal using ${ }^{173} \mathrm{Yb}$ and ${ }^{175} \mathrm{Lu}$ signals, and canonical ${ }^{176} \mathrm{Yb} /{ }^{173} \mathrm{Yb}$ and ${ }^{176} \mathrm{Lu} /{ }^{175} \mathrm{Lu}$ ratios. For analyses with relatively high $\mathrm{Yb} / \mathrm{Hf}\left({ }^{176} \mathrm{Yb} /{ }^{177} \mathrm{Hf}>0.055\right)$, the internal $\beta \mathrm{Yb}$ was typically used for the ${ }^{176} \mathrm{Yb}$ and ${ }^{176} \mathrm{Lu}$ interference corrections. For analyses with lower $\mathrm{Yb} / \mathrm{Hf}$, the internal $\beta \mathrm{Hf}$ was scaled by a factor ('Xbeta' = $\beta \mathrm{Yb} / \beta \mathrm{Hf}$ )—determined from bracketing measurements of MUNZirc4—and applied to the ${ }^{176} \mathrm{Yb}$ and ${ }^{176} \mathrm{Lu}$ interference corrections. This approach was adopted because of the poor precision on the internally determined $\beta Y \mathrm{~b}$ in low-Yb zircons. Interference- and mass-bias-corrected ${ }^{176} \mathrm{Hf} /{ }^{177} \mathrm{Hf}$ ratios were then normalised to ${ }^{176} \mathrm{Hf} /{ }^{177} \mathrm{Hf}=0.282482$ for the Plešovice reference zircon.

The reproducibility (mean $\pm 2 \mathrm{SD} ; n$ ) of the ${ }^{176} \mathrm{Hf} /{ }^{177} \mathrm{Hf}$ for each secondary reference zircon calculated with internally determined $\beta Y b$ was as follows: MUNZirc 1,3 , and $4(0.282139 \pm 45 ; 45)$, Mud Tank $(0.282495 \pm 31 ; 15)$ and $91500(0.282304 \pm 34 ; 11)$. For $176 \mathrm{Hf} / 177 \mathrm{Hf}$ calculated with the scaled $\beta \mathrm{Hf}$, the reproducibility was as follows: MUNZirc 1,3 , and $4(0.282135 \pm 34 ; 45)$, Mud Tank $(0.282513 \pm 20 ; 15)$ and $91500(0.282310 \pm 35 ; 11)$.

Initial ${ }^{176} \mathrm{Hf} /{ }^{177} \mathrm{Hf}\left({ }^{176} \mathrm{Hf} /{ }^{177} \mathrm{Hf}\right)$ was calculated using the corrected ${ }^{176} \mathrm{Hf} /{ }^{177} \mathrm{Hf}$ and ${ }^{176} \mathrm{Lu} / 1^{77} \mathrm{Hf}, \lambda^{176} \mathrm{Lu}=1.867$ $\times 10^{-11} \mathrm{yr}^{-1}$ (Söderlund et al., 2004), and the U-Pb date of the corresponding zircon domain. Initial $\varepsilon \mathrm{Hf}$ was calculated relative to CHUR (Bouvier et al., 2008) at the mean age determined for the dyke.

\section{Results}

$\mathrm{U}-\mathrm{Pb}$ zircon geochronological data are presented in Electronic Supplement 1 and Lu-Hf data from the same grains in Electronic Supplement 2. Whole-rock geochemical data are presented in Electronic Supplement 3.

\section{$\mathrm{U}-\mathrm{Pb}$ zircon geochronology}

Zircon was separated from a fine-grained, plagioclase-phyric felsic vein (Fig. 3E, F). The analysed zircon grains are between 100 and $200 \mu \mathrm{m}$, brownish-grey and equidimensional, with poorly developed crystal faces, to short prismatic (Fig. 4A). The interior textures of the grains range from well-developed oscillatory zoned, through somewhat irregular or sector zoned, to chaotic (Fig. 4B). Many of the grains have $\mathrm{CL}$-bright (U poor) rims that are typically only a few microns thick, or similar CL-bright material invading the grains along thin fractures that truncate the internal zoning in the grains.

Ten analyses were performed on the tape-mounted grains and 12 analyses on the epoxy-mounted grains, the latter targeting oscillatory-zoned grains. Apart from one strongly discordant analysis, the tape-mounted zircons yield ages that trend along a discordia with an upper intercept near $500 \mathrm{Ma}$ (Fig. 4C); however, most of the analyses are within $2 \sigma$ of the Concordia making it difficult to obtain a reliable age. In contrast, the analyses performed on the oscillatory-zoned, epoxy-mounted grains yield concordant data that cluster around $500 \mathrm{Ma}$ and yield a weighted average ${ }^{238} \mathrm{U} /{ }^{206} \mathrm{~Pb}$ age of $494 \pm 5$ $\mathrm{Ma}(2 \sigma, \mathrm{MSWD}=1.3)$. A regression through all 21 analyses (one strongly discordant analysis excluded) 

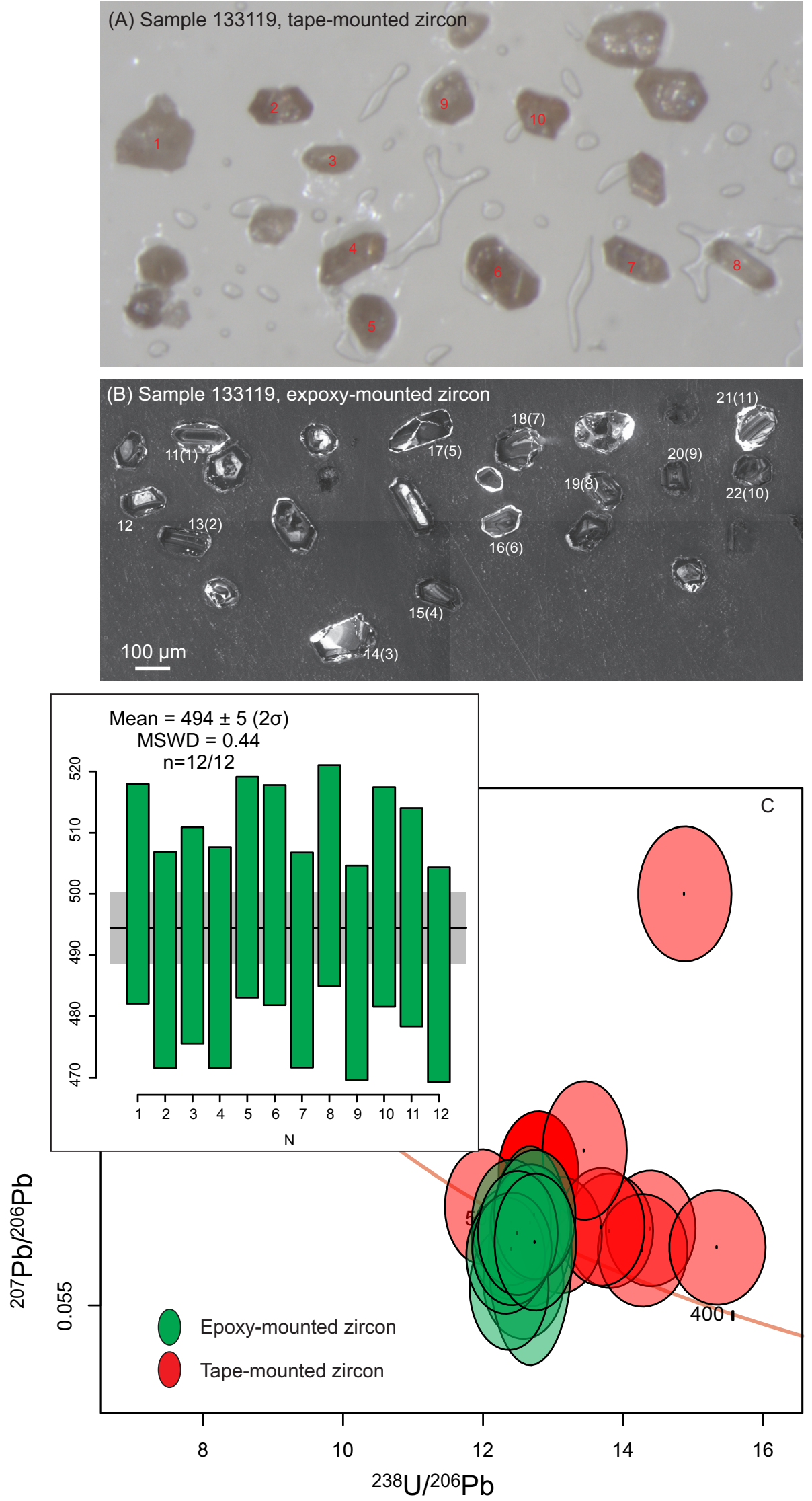

Figure 4. (A) Optical-light image of zircon grains from sample 133119 mounted on tape. Numbers in red refer to $\mathrm{U}-\mathrm{Pb}$ analyses performed on these tape-mounted grains, red numbers in Electronic Supplement 1. (B) CL image of zircon grains from the same sample, with white numbers corresponding to U-Pb analyses, black numbers in Electronic Supplement 2. Numbers in parenthesis refer to Lu-Hf analyses. (C) U-Pb data from tape-mounted (red) and epoxymounted (black) zircons. The final, weighted average ${ }^{238} \mathrm{U} / 206 \mathrm{~Pb}$ age (inset) is based on all the analyses of epoxymounted zircons, 12 in all. 
yields a discordia with upper and lower intercepts of $487 \pm 11$ and $-21 \pm 200 \mathrm{Ma}$, respectively (MSWD $=1.5$ ), i.e., within error of the weighted average age of the oscillatory-zoned zircons. We therefore take $494 \pm 5 \mathrm{Ma}$ to be the best estimate of the crystallisation age of the tonalitic dyke cutting the Lillevik ophiolite fragment. Most of the analyses from the the tape-mounted zircons yield younger ages than the oscillatory-zoned interiors and with lower $U$ concentrations (average 260 vs. 614 ppm, respectively). Most likely, the analyses of the tape-mounted zircons represent mixes of U-poor rims and oscillatoryzoned interiors of the grains. Considering evidence for both Early Ordovician and Silurian metamorphism from other parts of the Scandinavian Caledonides (Slagstad et al., 2020), it appears likely that the U-poor rims and transecting veins formed within a few tens of million years after crystallisation of the dyke, and result in a discordia nearly parallel to the Concordia.

\section{Lu-Hf isotopes in zircon}

Eleven analyses of grains that yielded near-concordant, c. $494 \mathrm{Ma}$ ages returned $\varepsilon^{\mathrm{Hf}}{ }_{494}$ values between 6.2 and 9.9, with an average of 8.1, intermediate between depleted mantle (DM) and chondrite uniform reservoir (CHUR) at that time (Fig. 5).

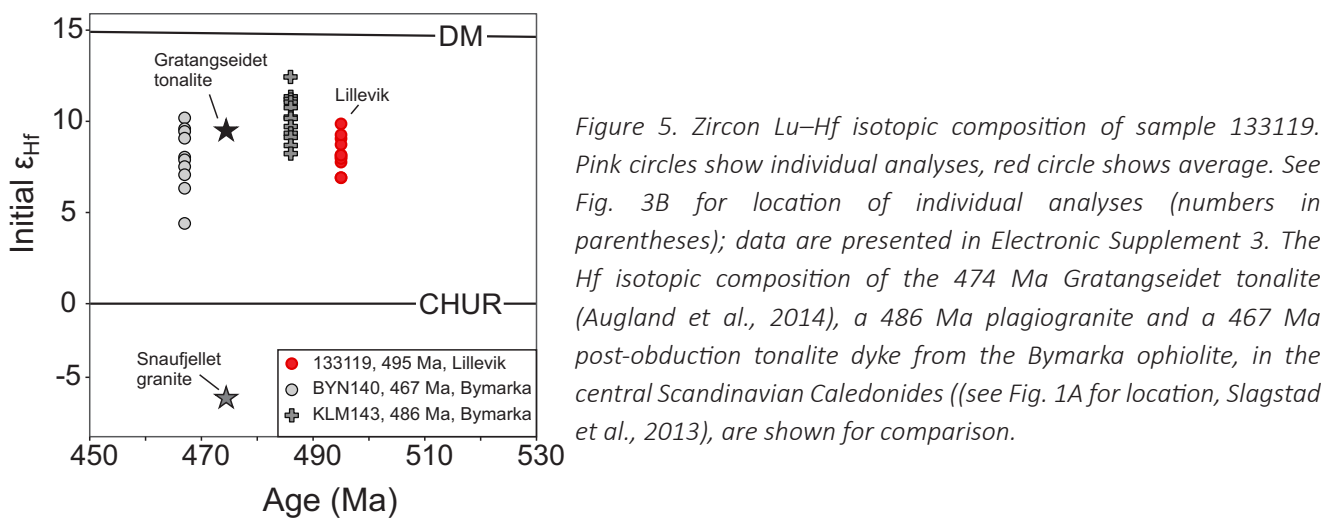

\section{Whole-rock geochemistry}

Only one new geochemical analysis - of the dated felsic vein - is presented here, rendering detailed interpretations of petrogenesis and tectonic environment impossible. For reference and completeness, the various plots shown in Fig. 6 also include data presented by Boyd (1983). The dated felsic vein plots

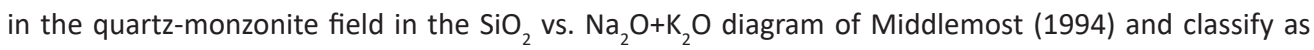
calc-alkaline in the AFM diagram of Irvine \& Baragar (1971), similar to the 'felsic veins' of Boyd (1983). The alkali-rich compositions of these rocks are mainly caused by very high $\mathrm{Na}_{2} \mathrm{O}$ (between 9.1 and 10.6 wt.\%), which may reflect secondary metamorphic processes rather than primary igneous compositions, a process also alluded to by Boyd (1983). The dated felsic vein displays a chondrite-normalised REE pattern that is strongly depleted in heavy REE (HREE), with a ( $\mathrm{La} / \mathrm{Yb}) \mathrm{N}$ ratio of 60 , somewhat higher than Boyd's felsic veins $\left((\mathrm{La} / \mathrm{Yb})_{N}=28\right.$ and 31). In the Primitive mantle-normalised diagram, the dated felsic vein displays a negative $\mathrm{Nb}$-Ta ratio, along with low $\mathrm{K}$. The latter may reflect alteration rather than a primary igneous composition.

Geochemical data from the mafic rocks - the dominant rock type in the Lillevik ophiolite fragment - are only available from the work of Boyd (1983) and briefly reiterated here. The compositionally layered gabbros appear to be the oldest rocks in the Lillevik ophiolite fragment and classify as tholeiitic to calc-alkaline basalts. The three samples plotting in the calc-alkaline field in the 


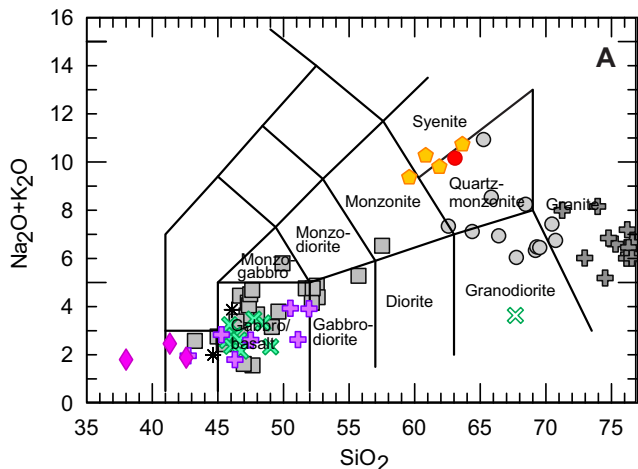

Mafic rocks
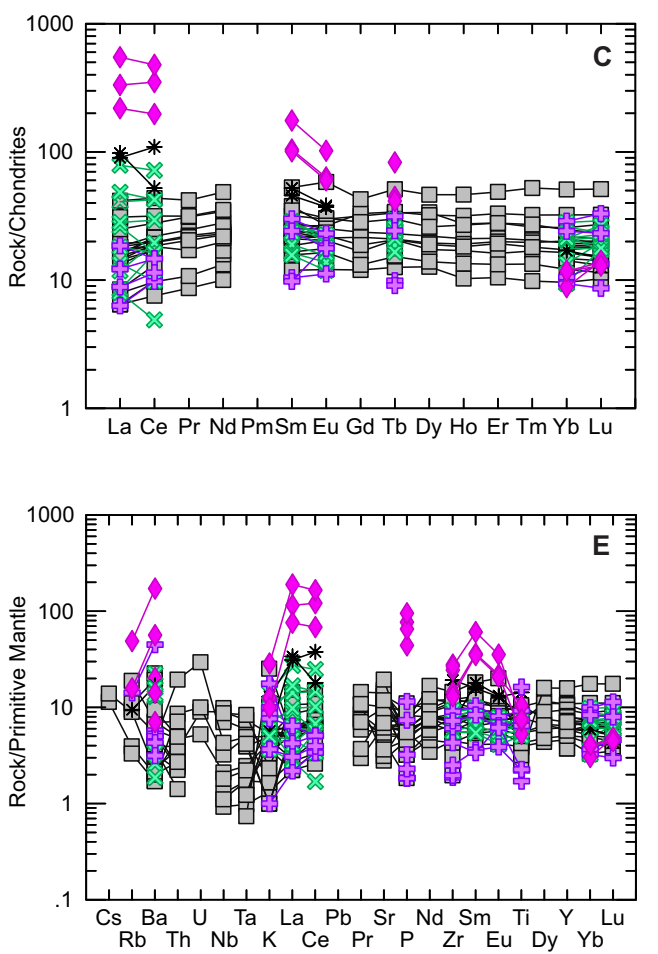

Cross-cutting dolerite dyke

¿abbroic dyke

$\checkmark$ Dolerite dyke

\{ Layered gabbro

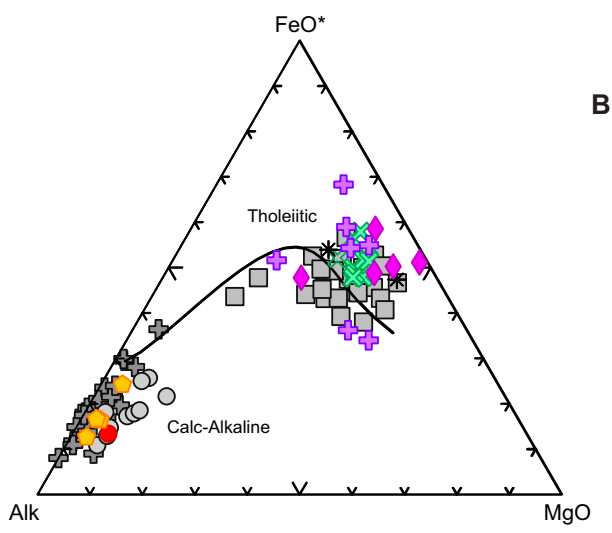

Felsic rocks
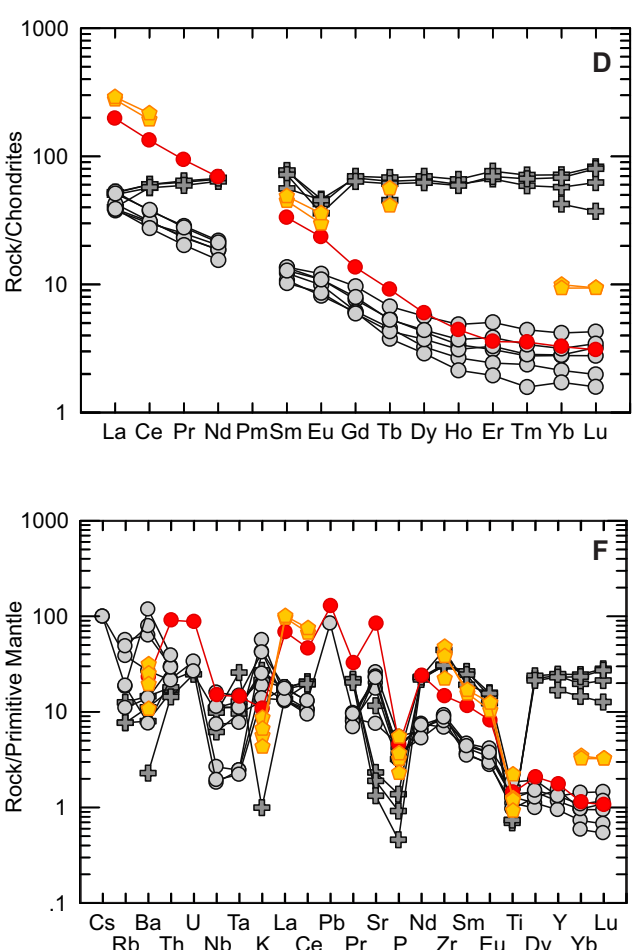

- Dated sample 133119

Leucocratic veins

Figure 6. Whole-rock geochemistry of sample 133119 from the Lillevik ophiolite fragment along with data compiled from Boyd (1983). For comparison, data from greenstones and associated 486 Ma plagiogranite and 467 Ma postobduction tonalite dyke from the Bymarka ophiolite, in the central Scandinavian Caledonides (see Fig. 1A for location), are shown. Data from Slagstad et al. (2013). (A) Total alkali vs. silica plot (Le Bas et al., 1986), (B) AFM diagram (Irvine \& Baragar, 1971), (C, D) chondrite-normalised and (E, F) primitive mantle-normalised spider diagrams, with normalising values from Sun \& McDonough (1989).

AFM diagram are characterised by enrichment in $\mathrm{Na}_{2} \mathrm{O}$ relative to the samples plotting in the tholeiitic field (2.6-3.8 vs 1.5-2.6 wt.\%), so may have been affected by secondary enrichment in $\mathrm{Na}$. The layered gabbros display flat REE patterns with a small depletion in light REE (LREE, $\left.\left.(\mathrm{La} / \mathrm{Yb})_{N}=0.4-1.2\right)\right)$, consistent with derivation from depleted mantle and similar to ophiolitic rocks elsewhere in the Scandinavian Caledonides (e.g., Slagstad et al., 2013). The layered gabbros are cut by at least two generations of basaltic tholeiitic dolerite dykes that display a range of trace element compositions, from LREE depleted, similar to the layered gabbros, to LREE enriched, with $(\mathrm{La} / \mathrm{Yb})_{\mathrm{N}}$ between 0.3 and 5.8 . 
This range of compositions may indicate changing tectonic environments, as observed in the $497 \mathrm{Ma}$ Leka ophiolite (Furnes et al., 1988) and 486 Ma Bymarka ophiolite (Slagstad et al., 2013). At present we are unable to link chemical composition to the relative age of the dykes; however, two dolerite dykes that post-date early deformation of the ophiolite fragment (Boyd, 1983), shown as black stars in Fig. 6, plot among the most LREE-enriched mafic dykes, supporting an interpretation of changing tectonic environment with time. The gabbro dykes have tholeitic basaltic compositions but are strongly enriched in LREE and other incompatible minor and trace elements such as $\mathrm{P}_{2} \mathrm{O}_{5}(0.93-2.07 \mathrm{wt} . \%)$ and $\operatorname{Zr}(146-311 \mathrm{ppm})$, even more so than the most enriched dolerite dykes.

\section{Discussion}

The age of $494 \pm 5 \mathrm{Ma}$ for a felsic vein in the Lillevik ophiolite fragment is one of the oldest ages obtained from ophiolites in the Scandinavian Caledonides, similar to an age of $497 \mathrm{Ma}$ for a plagiogranite at Leka and $495 \mathrm{Ma}$ for a trondhjemite sheet on Ytterøya, near Trondheim (Roberts \& Tucker, 1998). As discussed by Slagstad (2003) and Slagstad et al. (2013), isotopic and geochemical data show that magmatic rocks from ophiolites may reflect very different stages in the host ophiolite's history, from ocean-floor spreading through establishment of a convergent active-margin setting that eventually results in obduction of the ophiolite, to establishment of an active continental margin following obduction. The best example of such an evolution comes from felsic, ophiolite-hosted rocks in the Bymarka and Løkken ophiolites in the central Norwegian Caledonides, near Trondheim (Fig. 1). Here, Slagstad (2003) and Slagstad et al. (2013) argued that 487-486 Ma felsic rocks (plagiogranites) with LREE-depleted, flat REE patterns and near-depleted-mantle Sm-Nd and Lu-Hf isotopic compositions $\left(\varepsilon \mathrm{Nd}_{486}=6.2-6.3, \varepsilon \mathrm{Hf}_{486}=8.2-12.4\right)$ represent ophiolite formation at an oceanic spreading centre, most likely in a back-arc setting. Slightly younger, granodioritic intrusive rocks dated at $481 \mathrm{Ma}$ are enriched in LREE with flat M/HREE patterns and evolved isotopic compositions $\left(\varepsilon \mathrm{Nd}_{481}=-2.6--4.0, \varepsilon \mathrm{Hf}_{486}=3.8-\right.$ 6-4), and were interpreted to reflect a convergent arc setting associated with subduction of continentally derived sediments. Finally, tonalitic veins and dykes dated at $467 \mathrm{Ma}$ have strongly fractionated (HREE depleted) REE patterns, consistent with partial melting of mafic rocks in the presence of garnet. Slightly more evolved isotopic compositions $\left(\varepsilon \mathrm{Nd}_{467}=3.0-3.9, \varepsilon \mathrm{Hf}_{467}=4.4-10.2\right)$ than the plagiogranites and spatially and temporally associated calc-alkaline magmatic activity interpreted to represent an active continental-margin setting (Grenne \& Roberts, 1998), suggest that these younger felsic dykes formed by partial melting of a mafic thrust stack following ophiolite obduction and oceanic-arc accretion onto continental crust. Thus, the Bymarka and Løkken ophiolites represent c. 20 Myr of magmatic activity spanning a range of tectonic settings reflected in significant variation in isotopic and chemical composition.

Only sparse geochemical data are available from the Lillevik ophiolite fragment, limited to 28 analyses presented by Boyd (1983) and one new analysis of a felsic vein presented here. The latter is the only sample where a full suite of trace elements and isotopic data are available. Unfortunately, the sparsity of data hampers a detailed discussion of the tectonomagmatic evolution of the Lillevik ophiolite fragment and the Gratangseidet Igneous Complex. Field relationships suggest that the layered gabbros are the oldest rocks in the Lillevik ophiolite fragment, possibly along with some of the multi-generation dolerite dykes. The layered gabbros and some of the dolerite dykes display LREE-depleted compositions typical of mid-ocean ridge basalts found in ophiolites elsewhere in the Scandinavian Caledonides (Fig. 6). The younger mafic rocks, including gabbro dykes and post-deformation dolerite dykes, are strongly LREE enriched. Boyd (1983) interpreted this compositional change to reflect a change to ocean islandbasaltic magmatism. In other ophiolites in the Scandinavian Caledonides, with larger geochemical datasets available, a similar evolution from LREE-depleted to -enriched is observed (Slagstad et al., 2013). Here, this change has been interpreted to reflect a change from ocean-floor spreading to oceanic 
subduction and establishment of island arc systems or, alternatively, new continental active margins following ophiolite obduction. We note, however, that the HREE enrichments associated with the latter process are significantly smaller than that observed in the Lillevik ophiolite fragment.

The felsic veins, with their strongly fractionated REE patterns, are very different from typical plagiogranites characterised by flat, slightly LREE-depleted patterns (Fig. 6D). Thus, the geochemical data suggest that the $494 \mathrm{Ma}$ age obtained from one of them does not date ocean-floor spreading and ophiolite formation. Felsic veins and dykes of similar composition have been described from the Bymarka ophiolite (Fig. 6), where they were interpreted to have formed by partial melting of mafic rocks in the presence of garnet, following ophiolite obduction and stacking onto a continental margin (Slagstad et al., 2013). The Lu-Hf isotopic data from Lillevik are consistent with this interpretation, yielding slightly less juvenile, but overlapping, composition than observed in plagiogranites (Fig. 5). The observation that felsic veins, compositionally identical to the dated vein, cut an older tectonic fabric in the host rocks supports such an interpretation. We, therefore, tentatively interpret the $494 \mathrm{Ma}$ felsic vein in the Lillevik ophiolite fragment to provide a minimum age of ophiolite formation and obduction. We note that Lu-Hf isotopes alone cannot distinguish ophiolite-related felsic rocks from post-obduction felsic rocks, as both are likely to be relatively juvenile. In contrast, the lowpressure melting conditions during ophiolite formation are likely to produce melts with different trace element compositions compared to those formed during higher-pressure melting following obduction (Slagstad, 2003; Slagstad et al., 2013). Thus, chemical data are critical for determining the relationship between and tectonic significance of felsic rocks and their associated mafic host rocks. For these reasons it is also difficult to assign a tectonic significance to dated felsic rocks from the Gratangseidet Igneous Complex and the Lyngen ophiolite, which yield ages of 474 and 481 to $469 \mathrm{Ma}$, respectively (Oliver \& Krogh, 1995; Augland et al., 2014). Rather, the very evolved isotopic compositions of the $481 \mathrm{Ma}$ Holten tonalite in the Lyngen ophiolite $\left(\varepsilon \mathrm{Hf}_{481}\right.$ from -2.3 to -16.8 , Augland et al., 2014) show involvement of continental crust, apparently incompatible with ocean-floor spreading. Similar, large isotopic variations have been documented from felsic rocks in ophiolites in the Caledonides in Trøndelag, interpreted to reflect post-ophiolite-obduction magmatism (Slagstad et al., 2013). Although currently undated, a younger generation of felsic vein in the Lillevik ophiolite fragment (Fig. 3F) may correspond to the $474 \mathrm{Ma}$ felsic veins dated by Augland et al. (2014), only about a kilometre away, in the Gratangseidet Igneous Complex, thus attesting to the complexity of this unit.

Cross-cutting relationships suggest that the gabbro dykes are younger than the felsic veins and that some of the dolerite dykes post-date deformation of the layered gabbros (Boyd, 1983). Although more geochronological, isotopic and geochemical data are needed, the currently available data and field relationships are consistent with the Lillevik ophiolite fragment preserving a yet poorly defined, complex magmatic history following ophiolite obduction, but prior to Scandian continent-continent collision and penetrative deformation at c. $430 \mathrm{Ma}$.

The available geochemical data and crystallisation ages of $494 \mathrm{Ma}$ for a felsic vein in the Lillevik ophiolite fragment, $474 \mathrm{Ma}$ for an isotopically juvenile $\left(\varepsilon \mathrm{Hf}_{474}=9.57\right)$ tonalite in the Gratangseidet Igneous Complex and $474 \mathrm{Ma}$ for an isotopically evolved $\left(\varepsilon \mathrm{Hf}_{474}=-6.22\right)$ A-type granite sill (Snaufjellet granite) in the Bogen Group (Augland et al., 2014), attest to a long-lived, tectonically varied magmatic evolution. Late Cambrian to Early Ordovician ophiolites have compositions indicative of formation above a subduction zone (e.g., oceanic back-arc, rifted island arc), consistent with new data from the Rödingsfiäll Nappe Complex (Uppermost Allochthon) in Central Norway documenting Late Cambrian active-margin processes in rocks currently residing at tectonostratigraphically high levels (Slagstad et al., 2020). Ophiolite formation was, in some cases, followed by at least 20 Myr of chemically and isotopically highly variable magmatic activity, probably reflecting the establishment of an active margin following obduction. The available data from the Lillevik ophiolite fragment appear consistent with a similar evolution here. 
The new data call into question the interpretation that the 481 to $469 \mathrm{Ma}$ tonalites from from the Lyngen ophiolite, Gratangseidet Igneous Complex and Ruggevik (Oliver \& Krogh, 1995; Northrup, 1997; Augland et al., 2014) represent the age of ophiolite formation (i.e., sea-floor spreading). The tectonic significance of these rocks needs to be tested geochemically.

\section{Conclusions}

A felsic vein in the Lillevik ophiolite fragment, dated at $494 \pm 5 \mathrm{Ma}$, provides a minimum age of ophiolite formation and most likely of obduction of the ophiolite. The available chemical data from the Lillevik ophiolite fragment and U-Pb zircon geochronological and Lu-Hf isotopic data from the Gratangseidet Igneous Complex and other, nearby units suggest a complex magmatic history, possibly with several stages of ophiolite formation, lasting at least $20 \mathrm{Myr}$, similar to ophiolite complexes farther south in the Scandinavian Caledonides. The new age also shows that Late Cambrian ophiolites, which are well documented in the southwestern and central Norwegian Caledonides, extend to the northernmost parts of the orogen, and that processes related to ophiolite formation and obduction were diachronous, but probably restricted to a c. 30-40 Myr period of time in the Late Cambrian through Early Ordovician. Ages of felsic units within ophiolites are generally taken to represent ocean-floor spreading and ophiolite formation, but such interpretations need to be corroborated by chemical data; many ophiolites preserve evidence of later felsic and mafic magmatic activity that may be completely unrelated to ophiolite formation.

Acknowledgements. Arild Andresen and Lars Eivind Augland are thanked for insightful comments. Per Terje Osmundsen is thanked for editorial handling of the manuscript. This article was carried out within the auspices of the MiMaC national infrastructure, project number 269842.

\section{References}

Andresen, A. \& Steltenpohl, M.G. 1994: Evidence for ophiolite obduction, terrane accretion and polyorogenic evolution of the north Scandinavian Caledonides. Tectonophysics 231, 59-70. https://doi.org/10.1016/0040-1951(94)90121-X.

Augland, L.E., Andresen, A., Gasser, D. \& Steltenpohl, M.G. 2014: Early Ordovician to Silurian evolution of exotic terranes in the Scandinavian Caledonides of the Ofoten-Troms area - terrane characterization and correlation based on new U-Pb zircon ages and Lu-Hf isotopic data. Geological Society, London, Special Publications 390, 655-678. https://doi.org/10.1144/SP390.19.

Bender, H., Glodny, J. \& Ring, U. 2019: Absolute timing of Caledonian orogenic wedge assembly, Central Sweden, constrained by Rb-Sr multi-mineral isochron data. Lithos 344-345, 339-359. https://doi.org/10.1016/j.lithos.2019.06.033.

Black, L.P., Kamo, S.L., Allen, C.M., Aleinikoff, J.N., Davis, D.W., Korsch, R.J. \& Foudoulis, C. 2003: TEMORA 1: A new zircon standard for Phanerozoic U-Pb geochronology. Chemical Geology 200, 155-170. https://doi.org/10.1016/S0009-2541(03)00165-7.

Blichert-Toft, J. 2008: The Hf isotopic composition of zircon reference material 91500. Chemical Geology 253, 252-257. https://doi.org/10.1016/j.chemgeo.2008.05.014. 
Bouvier, A., Vervoort, J.D. \& Patchett, P.J. 2008: The Lu-Hf and Sm-Nd isotopic composition of CHUR: Constraints from unequilibrated chondrites and implications for the bulk composition of terrestrial planets. Earth and Planetary Science Letters 273, 48-57. https://doi.org/10.1016/j.epsl.2008.06.010.

Boyd, R. 1983: The Lillevik dyke complex, Narvik: geochemistry and tectonic implications of a probable ophiolite fragment in the Caledonides of the Ofoten region, North Norway. Norsk Geologisk Tidsskrift 63, 39-54

Corfu, F., Andersen, T.B. \& Gasser, D. 2014: The Scandinavian Caledonides: main features, conceptual advances and critical questions. Geological Society, London, Special Publications 390, 9-43. https://doi.org/10.1144/SP390.25.

Dunning, G. \& Pedersen, R.-B. 1988: U/Pb ages of ophiolites and arc-related plutons of the Norwegian Caledonides: Implications for the development of lapetus. Contributions to Mineralogy and Petrology 98, 13-23. https://doi.org/10.1007/BF00371904.

Faber, C., Stünitz, H., Gasser, D., Jeřábek, P., Kraus, K., Corfu, F., Ravna, E.K. \& Konopásek, J. 2019: Anticlockwise metamorphic pressure-temperature paths and nappe stacking in the Reisa Nappe Complex in the Scandinavian Caledonides, northern Norway: evidence for weakening of lower continental crust before and during continental collision. Solid Earth 10, 117-148.

https://doi.org/10.5194/se-10-117-2019.

Fisher, C.M., Hanchar, J.M., Samson, S.D., Dhuime, B., Blichert-Toft, J., Vervoort, J.D. \& Lam, R. 2011: Synthetic zircon doped with hafnium and rare earth elements: A reference material for in situ hafnium isotope analysis. Chemical Geology 286, 32-47. https://doi.org/10.1016/j.chemgeo.2011.04.013.

Flem, B., Grimstvedt, A., Slagstad, T. \& Skår, Ø. 2005: Bulkanalyse av Th og U i bergartsprøver med LA-ICP-MS. Metodebeskrivelse. NGU Report 2005.031, 25 pp.

Froitzheim, N., Miladinova, I., Janák, M., Kullerud, K., Ravna, E.K., Majka, J., Fonseca, R.O.C., Münker, C. \& Nagel, T.J. 2016: Devonian subduction and syncollisional exhumation of continental crust in Lofoten, Norway. Geology 44, 223-226. https://doi.org/10.1130/G37545.1.

Furnes, H., Pedersen, R.-B. \& Stillman, C.J. 1988: The Leka Ophiolite Complex, central Norwegian Caledonides: Field characteristics and geotectonic significance. Journal of the Geological Society of London 145, 401-412. https://doi.org/10.1144/gsjgs.145.3.0401.

Gasser, D., Jeřábek, P., Faber, C., Stünitz, H., Menegon, L., Corfu, F., Erambert, M. \& Whitehouse, M.J. 2015: Behaviour of geochronometers and timing of metamorphic reactions during deformation at lower crustal conditions: phase equilibrium modelling and U-Pb dating of zircon, monazite, rutile and titanite from the Kalak Nappe Complex, northern Norway. Journal of Metamorphic Geology 33, 513-534. https://doi.org/10.1111/jmg.12131.

Gee, D.G., Kumpulainen, R.A., Roberts, D., Stephens, M.B., Thon, A. \& Zachrisson, E. 1985: Scandinavian Caledonides tectonostratigraphic map, 1:2,000,000, Sveriges Geologiska Undersökning, Ser. Ba NR 35.

Grenne, T. 1989: Magmatic evolution of the Løkken SSZ Ophiolite, Norwegian Caledonides: Relationship between anomalous lavas and high-level intrusions. Geological Journal 24, 251-274.

https://doi.org/10.1002/gj.3350240403. 
Grenne, T. \& Roberts, D. 1998: The Hølonda Porphyrites, Norwegian Caledonides: Geochemistry and tectonic setting of Early-Mid-Ordovician shoshonitic volcanism. Journal of the Geological Society of London 155, 131-142. https://doi.org/10.1144/gsjgs.155.1.0131.

Gustavson, M. 1974: Bedrock geological map Narvik, 1:250,000, Geological Survey of Norway.

Hacker, B.R. \& Gans, P.B. 2005: Continental collisions and the creation of ultrahigh-pressure terranes: Petrology and thermochronology of nappes in the central Scandinavian Caledonides. Geological Society of America Bulletin 117, 117-134. https://doi.org/10.1130/B25549.1.

Hodges, K.V. 1985: Tectonic stratigraphy and structural evolution of the Efiord-Sitasjaure area, North Scandinavian Caledonides. Norges Geologiske Undersøkelse Bulletin 399, 41-60.

Irvine, T.N. \& Baragar, W.R.A. 1971: A guide to the chemical classification of the common volcanic rocks. Canadian Journal of Earth Sciences 8, 523-548. https://doi.org/10.1139/e71-055.

Jackson, S.E., Pearson, N.J., Griffin, W.L. \& Belousova, E.A. 2004: The application of laser ablationinductively coupled plasma-mass spectrometry to in situ U-Pb zircon geochronology. Chemical Geology 211, 47-69. https://doi.org/10.1016/j.chemgeo.2004.06.017.

Jakob, J., Alsaif, M., Corfu, F. \& Andersen, T.B. 2017: Age and origin of thin discontinuous gneiss sheets in the distal domain of the magma-poor hyperextended pre-Caledonian margin of Baltica, southern Norway. Journal of the Geological Society, London 174, 557-571. https://doi.org/10.1144/jgs2016-049.

Kirkland, C.L., Daly, J.S. \& Whitehouse, M.J. 2007: Provenance and terrane evolution of the Kalak Nappe Complex, Norwegian Caledonides: Implications for Neoproterozoic Paleogeography and tectonics. Journal of Geology 115, 21-41. https://doi.org/10.1086/509247.

Kirkland, C.L., Slagstad, T. \& Johnson, T.E. 2018: Zircon as a metamorphic timekeeper: A case study from the Caledonides of central Norway. Gondwana Research 61, 63-72.

https://doi.org/10.1016/j.gr.2018.05.005.

Le Bas, M.J., Le Maitre, R.W., Streckeisen, A., Zanettin, B. \& Rocks, I.S.o.t.S.o.I. 1986: A Chemical Classification of Volcanic Rocks Based on the Total Alkali-Silica Diagram. Journal of Petrology 27, 745750. https://doi.org/10.1093/petrology/27.3.745.

Melezhik, V.A., Gorokhov, I.M., Fallick, A.E., Roberts, D., Kuznetsov, A.B., Zwaan, B.K. \& Pokrovsky, B.G. 2002a: Isotopic stratigraphy suggests Neoproterozoic ages and Laurentian ancestry for high-grade marbles from the north-central Norwegian Caledonides. Geological Magazine 139, 375-393. https://doi.org/10.1017/S0016756802006726.

Melezhik, V.A., Roberts, D., Gorokhov, I.M., Fallick, A.E., Zwaan, K.B., Kuznetsov, A.B. \& Pokrovsky, B.G. 2002b: Isotopic evidence for a complex Neoproterozoic to Silurian rock assemblage in the north-central Norwegian Caledonides. Precambrian Research 114, 55-86.

https://doi.org/10.1016/S0301-9268(01)00218-2.

Melezhik, V.A., Zwaan, B.K., Motuza, G., Roberts, D., Solli, A., Fallick, A.E., Gorokhov, I.M. \& Kusnetzov, A.B. 2003: New insights into the geology of high-grade Caledonian marbles based on isotope chemostratigraphy. Norwegian Journal of Geology 83, 209-242. 
Melezhik, V.A., Ihlen, P.M., Kuznetsov, A.B., Gjelle, S., Solli, A., Gorokhov, I.M., Fallick, A.E., Sandstad, J.S. \& Bjerkgård, T. 2015: Pre-Sturtian (800-730 Ma) depositional age of carbonates in sedimentary sequences hosting stratiform iron ores in the Uppermost Allochthon of the Norwegian Caledonides: A chemostratigraphic approach. Precambrian Research 261, 272-299. https://doi.org/10.1016/j.precamres.2015.02.015.

Melezhik, V.A., Ihlen, P.M., Bjerkgård, T., Sandstad, J.S., Raaness, A., Kuznetsov, A.B., Solli, A., Gorokhov, I.M., Pokrovsky, B.G. \& Fallick, A.E. 2018: A common mid-Neoproterozoic chemostratigraphic depositional age of marbles and associated iron formations ( $\mathrm{Fe} \pm \mathrm{Mn} \pm \mathrm{P}$ ) in the Scandinavian Caledonides. Norwegian Journal of Geology 98, 405-459. https://doi.org/10.17850/njg98-3-07.

Meyer, G.B., Grenne, G. \& Pedersen, R.B. 2003: Age and tectonic setting of the Nesåa Batholith: Implications for Ordovician arc development in the Caledonides of Central Norway. Geological Magazine 140, 573-594. https://doi.org/10.1017/\$0016756803008069.

Middlemost, E.A.K. 1994: Naming materials in the magma/igneous rock system. Earth-Science Reviews 37, 215-224. https://doi.org/10.1016/0012-8252(94)90029-9.

Northrup, C.J. 1997: Timing of structural assembly, metamorphism, and cooling of Caledonian Nappes in the Ofoten-Efjorden Area, North Norway: Tectonic insights from $\mathrm{U}-\mathrm{Pb}$ and ${ }^{40} \mathrm{Ar} /{ }^{39} \mathrm{Ar}$ geochronology. Journal of Geology 105, 565-582. https://doi.org/10.1086/515958.

Oliver, G.H.J. \& Krogh, T.E. 1995: U-Pb zircon age of 469 \pm 5 Ma for a metatonalite from the Kjosen Unit of the Lyngen Magmatic Complex, northern Norway. Norges Geologiske Undersøkelse Bulletin 428, 27-32.

Patchett, P.J. \& Tatsumoto, M. 1980: Hafnium isotope variations in oceanic basalts. Geophysical Research Letters 7, 1077-1080. https://doi.org/10.1029/GL007i012p01077.

Patchett, P.J. \& Tatsumoto, M. 1981: A routine high-precision method for Lu-Hf isotope geochemistry and chronology. Contributions to Mineralogy and Petrology 75, 263-267.

https://doi.org/10.1007/BF01166766.

Roberts, D. \& Gee, D.G. 1985: An introduction to the structure of the Scandinavian Caledonides. In Gee, D.G. \& Sturt, B.A. (eds.): The Caledonide Orogen - Scandinavia and Related Areas, John Wiley \& Sons, Chichester, pp. 55-68.

Roberts, D. \& Tucker, R.D. 1998: Late Cambrian U-Pb zircon age of a meta-trondhjemite from Ytterøya, Trondheimsfjorden, central Norwegian Caledonides. Norsk Geologisk Tidsskrift 78, 253-258.

Segal, I., Halicz, L. \& Platzner, I.T. 2003: Accurate isotope ratio measurements of ytterbium by multiple collection inductively coupled plasma mass spectrometry applying erbium and hafnium in an improved double external normalization procedure. Journal of Analytical Atomic Spectrometry 18, 1217-1223. https://doi.org/10.1039/b307016f.

Skår, Ø. 2002: U-Pb geochronology and geochemistry of early Proterozoic rocks of the tectonic basement windows in central Nordland, Caledonides of north-central Norway. Precambrian Research 116, 265-283. https://doi.org/10.1016/S0301-9268(02)00026-8.

Slagstad, T. 2003: Geochemistry of trondhjemites and mafic rocks in the Bymarka ophiolite fragment, Trondheim, Norway: Petrogenesis and tectonic implications. Norsk Geologisk Tidsskrift 83, 167-185. 
Slagstad, T., Melezhik, V.A., Kirkland, C.L., Zwaan, K.B., Roberts, D., Gorokhov, I.M. \& Fallick, A.E. 2006: Carbonate isotope chemostratigraphy suggests revisions to the geological history of the West Finnmark Caledonides, North Norway. Journal of the Geological Society of London 163, 277-289. https://doi.org/10.1144/0016-764905-021.

Slagstad, T., Pin, C., Roberts, D., Kirkland, C.L., Grenne, T., Dunning, G., Sauer, S. \& Andersen, T. 2014: Tectonomagmatic evolution of the Early Ordovician suprasubduction-zone ophiolites of the Trondheim Region, Mid-Norwegian Caledonides. Geological Society, London, Special Publications 390, 541-560. https://doi.org/10.1144/SP390.11.

Slagstad, T. \& Kirkland, C.L. 2017: The use of detrital zircon data in terrane analysis: A nonunique answer to provenance and tectonostratigraphic position in the Scandinavian Caledonides. Lithosphere 9, 1002-1011. https://doi.org/10.1130/L663.1.

Slagstad, T. \& Kirkland, C.L. 2018: Timing of collision initiation and location of the Scandian orogenic suture in the Scandinavian Caledonides. Terra Nova 30, 179-188. https://doi.org/10.1111/ter.12324.

Slagstad, T., Saalmann, K., Kirkland, C.L., Høyen, A.B., Storruste, B.K., Coint, N., Pin, C., Marker, M., Bjerkgård, T., Krill, A.G., Solli, A., Boyd, R., Angvik, T.L. \& Larsen, R.B. 2020: Late Neoproterozoic through Silurian tectonic evolution of the Rödingsfjället Nappe Complex, orogen-scale correlations and implications for the Scandian suture. Geological Society, London, Special Publications 503. SP5032020-10. https://doi.org/10.1144/SP503-2020-10.

Sláma, J., Košler, J., Condon, D.J., Crowley, J.L., Gerdes, A., Hanchar, J.M., Horstwood, M.S.A., Morris, G.A., Nasdala, L., Norberg, N., Schaltegger, U., Schoene, B., Tubrett, M.N. \& Whitehouse, M.J. 2008: Plešovice zircon - A new natural reference material for $\mathrm{U}-\mathrm{Pb}$ and $\mathrm{Hf}$ isotopic microanalysis. Chemical Geology 249, 1-35. https://doi.org/10.1016/j.chemgeo.2007.11.005.

Söderlund, U., Patchett, J.P., Vervoort, J.D. \& Isachsen, C.E. 2004: The 176Lu decay constant determined by $\mathrm{Lu}-\mathrm{Hf}$ and $\mathrm{U}-\mathrm{Pb}$ isotope systematics of Precambrian mafic intrusions. Earth and Planetary Science Letters 219, 311-324. https://doi.org/10.1016/S0012-821X(04)00012-3.

Steltenpohl, M.G., Andresen, A. \& Tull, J.F. 1990: Lithostratigraphic correlation of the Salangen (Ofoten) and Balsfjord (Troms) Groups: evidence for the post-Finnmarkian unconformity, north Norwegian Caledonides. Norges Geologiske Undersøkelse 418, 61-77.

Stephens, M.B., Gustavson, M., Ramberg, I.B. \& Zachrisson, E. 1985: The Caledonides of central-north Scandinavia-A tectonostratigraphic overview. In Gee, D.G. \& Sturt, B.A. (eds.): The Caledonide Orogen-Scandinavia and related areas, John Wiley \& Sons, Chichester, 135-162.

Sun, S.-s. \& McDonough, W.F. 1989: Chemical and isotopic systematics of oceanic basalts: Implications for mantle composition and processes. In Saunders, A.D. \& Norry, M.J. (eds.): Magmatism in the Ocean Basins, Geological Society of London Special Publication 42, 313-345.

https://doi.org/10.1144/GSL.SP.1989.042.01.19.

Van Achterbergh, E., Ryan, C.G., Jackson, S.E. \& Griffin, W.L. 2001: LA-ICP-MS in the Earth Sciences Appendix 3, data reduction software for LA-ICP-MS. In Sylvester, P.J. (ed.): Short Course volume 29: St.John's, Mineralogical Association of Canada, 239-243.

Vermeesch, P. 2018: IsoplotR: A free and open toolbox for geochronology. Geoscience Frontiers 9, 14791493. https://doi.org/10.1016/j.gsf.2018.04.001. 
Wiedenbeck, M., Allé, P., Corfu, F., Griffin, W.L., Meier, M., Oberli, F., Von Quadt, A., Roddick, J.C. \& Spiegel, W. 1995: Three natural zircon standards for U-Th-Pb, Lu-Hf, trace element and REE analyses. Geostandards Newsletter 19, 1-23. https://doi.org/10.1111/j.1751-908X.1995.tb00147.x.

Woodhead, J.D. \& Hergt, J.M. 2005: A preliminary appraisal of seven natural zircon reference materials for in situ $\mathrm{Hf}$ isotope determination. Geostandards and Geoanalytical Research 29, 183-195. https://doi.org/10.1111/j.1751-908X.2005.tb00891.x.

Zwaan, K.B., Fareth, E. \& Grogan, P.W. 1998: Bedrock geological map Tromsø, 1:250,000, Geological Survey of Norway. 